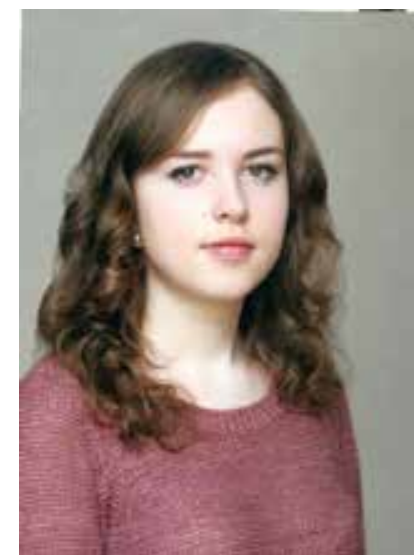

\title{
Аарина Ходаківська,
}

стуцентка IV курсу спеціальності

«Міжнародне право»

Інституту міжнародних вінносин

Київського національного університету

імені Тараса Шевченка,

ORCID: 0000-0002-5908-3061

https://doi.org/10.32782/2020-38-10

удк 341.1

\section{Внутрішнє право міжснародних організацій}

Постановка проблеми. У сучасному глобалізованому світі роль міжнародних організацій невпинно зростає, адже дедалі більше держав доходять висновку, що координація їхніх зусиль є більш ефективним способом протистояння поставленим світом викликам, ніж окремі дії кожної 3 них. Уже протягом не одного десятиріччя така співпраця відбувається переважно в рамках міжнародних організацій. Безумовно, перш ніж узятися до розробки рішень щодо глобальних проблем, міжнародній організації необхідно узгодити свою повсякденну внутрішню діяльність, деталізувати здійснення повноважень органами організації, визначити процедури розгляду питань та порядок прийняття рішень, встановити трудові відносини з персоналом тощо. Це означає, що для забезпечення функціонування міжнародним організаціям необхідні власні норми права, які врегульовували б їхню діяльність. I тому в рамках міжнародних організацій виробляються масиви відповідних норм, які в працях багатьох учених отримали узагальнену назву «внутрішнє право міжнародних організацій». При цьому питання про визначення, природу, особливості внутрішнього права міжнародних організацій, його співвідношення з міжнародним правом поки що не знайшли свого однозначного вирішення як у науковій літературі, так і на практиці.

Аналіз останніх досліджень i публікацій. Окремі аспекти права міжнародних організацій досліджувалися такими українськими науковцями, як І. Ахмад, К. Білляр, Я. Вільчак, Д. Денисова, Р. Єделєв, Д. Кулеба, С. Коваленко, О. Шпакович. Деякі з них, досліджуючи правотворчість міжнародних організацій, розробляли й окремі питання внутрішнього права міжнародних організацій. Так, у кандидатській дисертації І. Ахмада «Правотворчість міжнародних міжурядових організацій» було визначено коло правовідносин, які регулюються внутрішнім правом міжнародних організацій, і було доведено, що внутрішне право міжнародних організацій не зводиться лише до сукупності норм, які регулюють відносини 3 персоналом організації [1, с. 7]. О. Шпакович також у ході дослідження правотворчості 
міжнародних організацій і ухвалених ними правових актів, зокрема в кандидатській дисертації «Роль міжнародних економічних організацій в правотворчому процесі» зупинялася на питанні обов'язкового характеру актів, що регулюють питання внутрішнього права міжнародних організацій [2, с. 15], а більш детально внутрішне право міжнародних організацій було охоплене в монографії О. Шпакович «Вплив актів міжнародних організацій на внутрішні правопорядки держав-членів: теорія і практика», де, зокрема, надано визначення поняття внутрішнього права міжнародних організацій, наведено особливості юридичної природи його норм, а основним джерелом внутрішнього права міжнародних організацій визначено рішення органів міжнародних організацій, прийняті для врегулювання внутрішньоорганізаційних відносин [3, с. 146-147, с. 171-172].

Також право міжнародних організацій частково висвітлювалося в працях радянських, а згодом і російських вчених-правників, зокрема С. Малініна, В. Маргієва, М. Попова, Т. Нешатаєвої, Ю. Сарвіро, Є. Шибаєвої. Систематично та детально проблема безпосередньо внутрішнього права міжнародних організацій розглядалася лише В. Маргієвим у докторській дисертації «Внутреннее право международных организаций», де було з'ясовано поняття та правову природу внутрішнього права міжнародних організацій, юридичні підстави його створення, його джерела та його місце в системі міжнародного права [4]. Дослідженням цих питань займалась і Ю. Сарвіро в рамках одного 3 розділів своєї кандидатської дисертації «Внутреннее право международных организаций: на примере ЮНЕСКО » [5, c. 11-14].

Більшою мірою внесок до дослідження внутрішнього права міжнародних організацій зробили закордонні вчені, серед яких Ч. Ф. Амерасінгхе,
Дж. Балладоре Пальєрі, Р. Бернхардт, Н. Блоккер, Р. Вірзо, Л. Гасбаррі, Я. Клабберс, Е. Кляйн, Е. Лаутерпахт, Д. Г. Мехіа-Лемос, К. Пітерс, Ф. Сеєрстед, Г. Шермерс та інші. Тим не менш, і в цих науковців немає грунтовних спеціальних досліджень, які були б присвячені винятково внутрішньому праву міжнародних організацій: переважно або висвітлюються окремі питання, пов’язані з нормами внутрішнього права міжнародних організацій [6; 7; 8], або внутрішне право міжнародних організацій $є$ тільки незначною частиною колективної праці, що охоплює право міжнародних організацій у цілому $[9 ; 10 ; 11 ; 12]$.

Беручи до уваги вищевикладене, можемо зрозуміти, що теоретичні засади внутрішнього права міжнародних організацій, які стосуються його природи, системної приналежності, особливостей і джерел, продовжують бути доволі дискусійними та потребують більш детального дослідження, адже розуміння теоретичних засад внутрішнього права міжнародних організацій є необхідним для подальшої розробки його теоретичних і практичних питань. Ми спробуємо окреслити основні моменти дискусії довкола проблеми внутрішнього права міжнародних організацій та спрогнозувати іiі подальший розвиток.

Виклад матеріалу дослідження та його основні результати. Сьогодні важко уявити функціонування міжнародної організації без правових норм, які впорядковували б їі внутрішню діяльність. Про міжнародні організації в сучасному розумінні, згідно 3 панівною в науці точкою зору, прийнято говорити, починаючи з 1919 р., коли були створені Ліга Націй і Міжнародна організація праці [3, с. 19-20; 9, с. 5]. Проте концепція внутрішнього права міжнародних організацій не виникла одночасно з цим. На той час необхідність його існування взагалі не розглядалася. Переважно 
пропонувалося, як і у випадку неурядових організацій, застосовувати право держави перебування організації. Деякі вчені вважали за необхідне визначати застосовуване право за прив'язками 3 колізійного права, тобто намагалися включити елементи приватно-правового регулювання. Такими прив'язками були, наприклад, lex loci contractus (право держави місця укладення договору) для регулювання трудових відносин між організацією та її службовцем або lex rei sitae (право країни місцезнаходження речі) для регулювання відносин щодо нерухомого майна. Інші науковці відкидали можливість застосування будь-якого національного права, а натомість пропонували застосовувати загальні принципи права, а в разі неможливості їхнього застосування - принцип справедливості [13, с. 527].

Звісно, всі ці підходи мали істотні недоліки, що робило їхнє застосування недоцільним, а часто - й неможливим. Перший і другий підхід, передбачаючи, що регулювання, наприклад, трудових відносин між міжнародною організацією та іiї службовцями підпорядковується праву конкретної держави, а спори стосовно цих питань вирішуються національними судами, призводили до того, що міжнародна організація фактично втрачала свою самостійність від держав-членів. Слід зазначити, що другий підхід, який намагався поєднати приватно-правове регулювання 3 публічно-правовим, ймовірно, вплинув на появу концепції внутрішнього права міжнародних організацій як особливого правопорядку, яка буде детально розглянута нижче. Недолік же третього підходу полягав у його недостатності: загальні принципи права не могли забезпечити необхідну регламентацію специфічних внутрішньоорганізаційних відносин.

Унаслідок цього в середині XX ст., коли розпочався сучасний етап розвитку міжнародних організацій
[3, с. 22], уже не було сумнівів у необхідності створення комплексу норм для врегулювання внутрішньої діяльності міжнародних організацій.

Визначення внутрішнього права міжнародних організацій, які дають українські науковці, не містять принципових відмінностей.

I. Ахмад визначає внутрішне право міжнародних організацій як «сукупність норм, регулюючих структуру, порядок здійснення функцій, взаємовідносини між внутрішніми підрозділами міжнародної організації, а також статус і функції іï посадових осіб і службовців» [1, с. 13].

Більш детальне визначення дає О. Шпакович, згідно 3 яким «внутрішнє право міжнародних організацій є сукупністю юридичних норм, прийнятих і забезпечуваних міжнародною організацією в особі її органів, виражає волю самої організації і регулює відносини, що складаються в межах організації між її внутрішніми підрозділами, між організацією та їі членами, а також між організацією та іiї службовцями, між посадовими особами і персоналом організації» [3, с. 146].

В Енциклопедії міжнародного права подане таке визначення: «Внутрішне право міжнародних організацій - це комплекс норм, які створюються в кожній міжурядовій організації для врегулювання відносин iii внутрішньоорганізаційного механізму і тих відносин, які встановлюються між органами, посадовими особами та іншими співробітниками цієї організації» [14, с. 529].

Можна констатувати, що в сучасній українській науці склався більш-менш одноманітний підхід до визначення внутрішнього права міжнародних організацій.

Англомовна наука та практика, окрім терміна «внутрішне право організаціï» (internal law of the organization), послуговується також терміном «правила організації» (rules 
of the organization), використовуючи ї як взаємозамінні [6, с. 160].

Більш складним питанням, щодо якого тривали та подекуди продовжуються дискусії серед закордонних учених, $є$ природа внутрішнього права міжнародних організацій. Деякі 3 них ставили під сумнів навіть саме існування такого права. Наприклад, Дж. Балладоре Пальєрі стверджував, що «не існує внутрішнього правопорядку, незалежного від міжнародного права, який розвивався б від власного імені, а наявний тільки міжнародний правопорядок, від якого залежать можливості організації щодо встановлення певних правил». Організація, на думку Пальєрі, підкоряється лише міжнародному праву, а тому «дорозумілі» (фр. «implicite») повноваження організації, на які держави не дають чіткої згоди, виникають із мовчазної згоди держав або міжнародного звичаю, який нещодавно виник у їхніх інтересах [15, с. 16-17]. Проте така точка зору підтримки не знайшла. На сьогодні в західній науці міжнародного права склалися дві протилежних позиції щодо природи внутрішнього права міжнародних організацій і його місця в правовій системі.

Представники першої позиції вважають, що внутрішнє право міжнародних організацій є новим окремим правопорядком (sui generis), який спирається на установчий документ міжнародної організації, але є незалежним від будь-якого іншого правопорядку [10, c. 755]. Їхнім основним аргументом є те, що внутрішне право міжнародних організацій не може належати до міжнародного права, оскільки має не координаційний характер, а організаційний. Вони також апелюють до того, що внутрішньому праву міжнародних організацій притаманні власні механізми правотворчості, а також ієрархічність [11, с. 443], що кардинальним чином відрізняється від погоджувального характеру створення міжнародно-правових норм суб'єктами, які юридично не підпорядковані один одному.

Наведені аргументи, безумовно, є переконливими, це визнають і критики цієї позиції. Проте далі вони ставлять питання: яким чином можливо відмежувати від міжнародного права внутрішне право міжнародних організацій, якщо воно грунтується на нормах, передбачених установчим документом міжнародної організації, а отже, на міжнародному праві [11, с. 443]? Справді, навіть у ст. 5 Віденської конвенції про право міжнародних договорів зазначено, що вона застосовується до будь-якого договору, який є установчим актом міжнародної організації [16]. 3 цього випливає, що, намагаючись відокремити внутрішне право міжнародних організацій від міжнародного права, неминуче стикаємося 3 проблемою встановлення межі між першим і другим.

Тому прихильники другої позиції обстоюють, що внутрішне право міжнародних організацій належить до міжнародного права, хоч і є його відносно самостійною частиною. Окрім того факту, що з установчого договору міжнародної організації та його тлумачення випливають і саме внутрішне право, і його юридична сила, представники другої позиції наголошують також на тому, що держави-члени діють через органи міжнародної організації безпосередньо або надають цим органам уповноваження на певні дії [12, с. 144]. Тобто це і є міжнародне право, яке створюється шляхом узгодження позицій держав, що відповідає позитивістському підходу, одному з основних нині, до міжнародного права. Також заслуговує на увагу аналогія, яку пропонує проводити Ч. Ф. Амерасінгхе: як на внутрішньодержавному рівні корпоративне право є частиною національного права, так і внутрішне право міжнародних організацій належить до міжнародного права [9, с. 274]. 
У радянсько-російській і українській науці міжнародного права в цілому отримала схвалення друга позиція: норми внутрішнього права міжнародних організацій належать до міжнародного права в широкому сенсі та утворюють у його межах порівняно самостійний комплекс (галузь, підсистему) [3, с. $146 ; 4$, с. 8].

Не поставила крапку в питанні природи внутрішнього права міжнародних організацій і Комісія міжнародного права ООН, щоправда, висловивши більшу прихильність до другої позиції. У процесі роботи над Проєктом статей про відповідальність міжнародних організацій, а саме у 2003 р. в коментарі до проєкту статті 3 Комісія міжнародного права ООН зазначила таке: «...внутрішне право міжнародної організації не може бути чітко відокремлене від міжнародного права. Принаймні установчий документ міжнародної організації є міжнародним договором або іншим документом, який регулюється міжнародним правом; деякі інші елементи внутрішнього права організації можна розглядати як такі, що належать до міжнародного права [...]. Таким чином, зв'язки між міжнародним правом i внутрішнім правом міжнародної організації видаються занадто складними для того, щоб їх можна було схарактеризувати одним загальним принципом» [17, с. 24].

Зрештою, залишається погодитися саме з такою, попри іï̈ нечіткість, ідеєю Комісії міжнародного права ООН, оскільки точки зору на внутрішне право міжнародних організацій і як на окремий правопорядок, i як на частину міжнародного права не позбавлені недоліків. Погоджуючись у цілому з критикою, яка лунала від представників кожної з позицій на адресу представників іншої, хочемо зосередитися на раніше не озвучених проблемних моментах другої позиції, які, на нашу думку, занадто істотні, щоб виправдати «відносну самостійність» внутрішнього права міжнародних організацій у рамках міжнародного права.

По-перше, суб’єктний склад відносин, що регулюється міжнародним правом, і відносин, що регулюється внутрішнім правом міжнародних організацій, не збігається. Виходячи 3 вищенаведених визначень внутрішнього права міжнародної організації, його суб'єктами є міжнародні організації, їхні органи, їхні підрозділи та їхні службовці. Серед них суб'єктами міжнародного права однозначно можна назвати лише міжнародні організації: правосуб'єктність індивіда в міжнародному праві залишається питанням, яке широко дискутується, а про міжнародну правосуб'єктність органів і підрозділів міжнародної організації взагалі не йшлося. А отже, видається дивним, що коло суб'єктів міжнародного права та коло суб'єктів внутрішнього права міжнародних організацій, нібито частини міжнародного права, настільки не збігаються.

По-друге, не можна однозначно стверджувати, що міжнародне право та внутрішне право міжнародних організацій мають ті самі джерела.

На думку В. Маргієва, який, як зазначалося вище, поділяе позицію щодо внутрішнього права міжнародних організацій як відносно самостійної частини міжнародного права, джерелами внутрішнього права міжнародних організацій слід вважати міжнародний договір, рішення органів міжнародної організації, міжнародний звичай і загальні принципи права [4, с. 29].

Найбільші сумніви викликає міжнародний звичай як джерело внутрішнього права міжнародних організацій. Були спроби виокремити «звичаєве право міжнародних організацій» як наслідок накопичення практики щодо тлумачення установчих актів та інших правових документів, які стосуються структури та діяльності міжнародної 
організації [18, с. 402]. Нині ж під звичаєвим правом міжнародної організації розуміють ii усталену практику, яка формується організацією та застосовується лише щодо неї самої [7, с. 630-631]. Погодившись із таким розумінням, Спеціальний доповідач М. Вуд у рамках роботи Комісії міжнародного права ООН над темою «Виявлення міжнародного звичаєвого права» зазначив, що хоча внутрішня усталена практика організації може за певних обставин породжувати своєрідне звичаєве право, вона, на відміну від зовнішньої усталеної практики (поведінка міжнародної організації у відносинах із державами, міжнародними організаціями та іншими суб'єктами), не стосується формування та виявлення міжнародного звичаєвого права [19, с. 49-50]. Таким чином, усталена практика у внутрішньому праві міжнародної організації відрізняється від міжнародного звичаю як джерела загального міжнародного права.

Певний внесок до визначення джерел внутрішнього права міжнародних організацій зробила знову-таки Комісія міжнародного права ООН. Хоча вона не ставила такої мети, а лише послідовно визначала, що означають правила міжнародної організації для двох розроблених нею документів, вважаємо, що цим вона окреслила коло джерел внутрішнього права міжнародних організацій.

У ст. 2(1)(j) Віденської конвенції про право договорів між державами та міжнародними організаціями або між міжнародними організаціями 1986 р., визначено, що для цілей цієї Конвенції правила організації означають, зокрема, установчі акти організації, рішення та резолюції, ухвалені відповідно до них, а також усталену практику організації [20].

Згодом, у 2011 р., Комісія міжнародного права ООН завершила роботу над Проєктом статей про відповідальність міжнародних організацій, де в ст. 2 (b) майже дослівно повторила попереднє визначення, розроблене нею, лише додавши до рішень і резолюцій «інші акти міжнародної організації» [21, с. 73].

Проте в коментарях до цього Проєкту статей Комісія міжнародного права ООН зазначила, що «слово «зокрема» було збережене, оскільки правила організації можуть також включати такі інструменти, як-от угоди, укладені організацією 3 третіми сторонами, і судові чи арбітражні рішення, які є обов'язковими для цієї організації» [21, с. 78].

Отже, доробок Комісії міжнародного права ООН дає змогу визначити такі джерела внутрішнього права міжнародної організації: установчий акт; рішення, резолюції та інші акти міжнародної організації; усталена практика організації; угоди, укладені організацією 3 третіми сторонами; судові чи арбітражні рішення, які є обов'язковими для цієї організації. Розглянемо роль кожного з цих джерел у теорії та на практиці.

1. Установчий акт міжнародної організації зазвичай містить лише найбільш загальні норми внутрішнього права міжнародної організації. Їх можна поділити на дві групи: «норми, які безпосередньо регулюють внутрішнє життя організації, та норми, які уповноважують організацію ухвалювати норми свого внутрішнього права» [4, с. 31]. Часто в одному установчому документі містяться й ті, й інші. Наприклад, ст. 20 Статуту Ради Свропи [22] визначає конкретні питання, щодо яких резолюції Комітету Міністрів ухвалюються одностайно, чи простою більшістю, чи більшістю у дві третини голосів. Прикладом норми з другої групи є положення ст. 16 Статуту Ради Європи, згідно 3 яким Комітет Міністрів приймає обов'язкові до виконання рішення з усіх питань, що стосуються внутрішньої організації та процедур 
Ради Європи, і з цією метою Комітет Міністрів затверджує необхідні фінансові та адміністративні правила.

2. Рішення, резолюції та інші акти міжнародних організацій є найбільш поширеним джерелом внутрішнього права міжнародних організацій. Це призводить до того, що деякі науковці під внутрішнім правом міжнародних організацій розуміють тільки ухвалені органами організації правила [9, с. 273-274; 10, с. 756-758]. Рішення, резолюції та інші акти органи міжнародної організації ухвалюють на виконання положень установчого документу та в межах передбачених ним повноважень. Нерідко деякі повноваження прямо передбачаються установчим актом міжнародної організації - найчастіше на ухвалення органами міжнародної організації власних правил процедури. Наприклад, у ст. 21, 30, 72, 90 Статуту ООН зазначено, що відповідно Генеральна Асамблея, Рада Безпеки, Економічна і Соціальна Рада, Рада 3 опіки встановлюють власні правила процедури. Відповідне положення містить і ст. 30 Статуту Міжнародного Суду ООН як невід'ємної частини Статуту ООН [23]. Метою таких положень є забезпечення функціональної та організаційної автономії органів організації [8, с. 299]. Стосовно обмеженості повноважень слід також звернути увагу на те, що Міжнародний Суд ООН у консультативному висновку Certain Expenses of the United Nations (1962) зазначив, що акт Генеральної Асамблеї ООН може бути дійсним навіть тоді, якщо Генеральна Асамблея перевищила власні повноваження (але не повноваження Організаціiі) [24, с. 169].

3. Усталена практика міжнародної організації створюється в процесі діяльності цієї організації. Чималий обсяг усталеної практики сформувався у внутрішньому праві ООН. Наприклад, у 1946 р., на самому початку діяльності Ради Безпеки
ООН, представник СРСР А. Громико заявив, що утримається від голосування, щоб не перешкоджати прийняттю резолюції. Таке утримання не було передбачено ні Статутом ООН, ні Тимчасовими правилами процедури Ради Безпеки, але внаслідок цього в практиці Ради Безпеки ООН сформувалося правило, згідно з яким утримання від голосування не розглядається як накладення вето [13, с. 22-23]. Щодо цього згодом висловився Міжнародний Суд ООН у консультативному висновку Legal Consequences for States of the Contitiued Presence of South Africa in Namibia (South West Africa) notwithstanding Security Council Resolution 276 (1970): «... процесуальна діяльність Ради Безпеки [...] послідовно та одноманітно тлумачить практику добровільного утримання постійним членом як таку, що не становить перешкоди для прийняття резолюцій. Утримуючись, член не виявляє свого заперечення щодо схвалення того, що пропонується; щоб перешкодити прийняттю резолюції, яка вимагає одноголосності постійних членів, постійний член повинен тільки проголосувати проти. Ця процедура, якої дотримується Рада Безпеки та яка залишилася незмінною після внесення змін до статті 27 Статуту стала загальноприйнятою для членів Ради Безпеки ООН та свідчить про загальну практику цієї організації» [25, с. 22].

4. Укладення договорів та угод 3 іншими суб'єктами міжнародного права визнається як право міжнародної організації, а відповідне положення зазвичай міститься в статуті. Хоча відносини між міжнародними організаціями за загальним правилом не охоплюватимуться внутрішнім правом однієї 3 них, укладені ними угоди можуть містити й положення про адміністративне співробітництво та співробітництво стосовно персоналу, що впливатиме на внутрішнє право кожної з цих організацій. Це, зокрема, стосується угод, 
якими спеціалізовані установи ООН ставляться у зв'язок із ООН [26].

5. Обов'язкові судові та арбітражні рішення, які стосуються внутрішнього права міжнародних організацій, мають право ухвалювати адміністративні трибунали, що створюються в рамках окремих міжнародних організацій для розв'язання спорів між організацією та іiі службовцями. Такі трибунали діють у рамках $\mathrm{OOH}, \mathrm{MOП,} \mathrm{Світового}$ банку, ОЕСР, Ліги арабських держав тощо [10, с. 462-467]. У цьому контексті слід звернути увагу на консультативний висновок Міжнародного Суду $\mathrm{OOH}$ Effect of awards of compensation made by the U. N. Administrative Tribunal (1954) [27]. Суд зазначив, що створений Генеральною Асамблеєю Адміністративний трибунал $\mathrm{OOH} є$ не просто дорадчим або підвідомчим органом, а $€$ незалежним і по-справжньому судовим органом, який ухвалює остаточні судові рішення в межах своїх функцій. А отже, його рішення є обов'язковими для ООН і відповідно для самої Генеральної Асамблеї.

Висновки. Поява концепції внутрішнього права міжнародних організацій була зумовлена, по-перше, особливостями внутрішньої організаційної структури міжнародних організацій, специфічністю відносин всередині організацій та необхідністю регламентації та впорядкування цих відносин, а по-друге, потребою в забезпеченні самостійності міжнародних організацій від держав-членів.

На сучасному етапі не вважаємо за можливе однозначно визначити природу внутрішнього права міжнародних організацій. 3 одного боку, не можна з упевненістю стверджувати, що внутрішне право міжнародних організацій є окремим правопорядком, адже основою внутрішнього права міжнародних організацій є, передусім, іiі установчий акт, що є міжнародним договором, а отже, регулюється міжнародним правом. 3 іншого боку, внутрішнє право міжнародних організацій не можна беззаперечно назвати частиною міжнародного права, оскільки в цьому разі ми зіткнемося з проблемою невідповідності між суб'єктами й джерелами міжнародного права та внутрішнього права міжнародних організацій.

Суб'єктами внутрішнього права міжнародних організацій є міжнародні організації, а також їхні органи, підрозділи та службовці. Таке коло суб'єктів практично не збігається з колом суб'єктів міжнародного права, незважаючи на дискусії щодо визначення останнього кола.

Джерела внутрішнього права міжнародних організацій є окремими для кожної з них, і до цих джерел можуть належати такі: 1) установчий акт цієї організації; 2) ухвалені організацією акти, зокрема рішення та резолюції; 3) усталена практика організації; 4) укладені організацією угоди з третіми сторонами; 5) обов’язкові для цієї організації судові чи арбітражні рішення.

Отже, вважаємо, що залишається неабиякий простір для дискусії стосовно теоретичних засад внутрішнього права міжнародних організацій, а тому передбачаємо, що в майбутньому ще з'являтимуться праці, у яких досліджуватимуться питання, які ми нині спробували охопити та проаналізувати. Зрештою, розвиток цієї дискусії приведе до вдосконалення практичної діяльності міжнародних організацій.

\section{Список використаних джерел}

1. Ахмад I. Правотворчість міжнародних міжурядових організацій : автореф. дис. ... канд. юр. наук : 12.00.11 / Київ. нац. ун-т ім. Т. Шевченка. Київ, 1999. 18 с.

2. Шпакович О. М. Роль міжнародних економічних організацій в правотворчому процесі : Автореф. дис. ... канд. юрид. наук : 12.00 .11 / Київ. нац. ун-т ім. Т. Шевченка. Київ, 2003. 20 с. 
3. Шпакович О. М. Вплив актів міжнародних організацій на внутрішні правопорядки держав-членів: теорія і практика : монографія. Київ : Видавничо-поліграфічний центр «Київський університет», 2011. 415 с.

4. Маргиев В. И. Внутреннее право международных организаций : автореф. дисс. ... д-ра юрид. наук : 12.00.10 / Казанский гос. ун-т. Казань, 1999. 42 с.

5. Сарвиро Ю. А. Внутреннее право международных организаций : на примере ЮНЕСКО : автореф. дисс. ... канд. юрид. наук : 12.00.10 / Рос. ун-т дружбы народов. Москва, 2009. 25 с.

6. Mejía Lemos D. G. The Law of International Organisations: «Internal» or «International»? A Critical Analysis of the Relevant Practice of the United Nations Codification Organs Revista chilena de derecho y ciencia política. Vol. 5, №. 2, 2014, P. 141-163.

7. Peters C. Subsequent Practice and Established Practice of International Organizations: Two Sides of the Same Coin? Goettingen Journal of International Law. Volume 3 (2011). P. 617-642.

8. Virzo R. The Proliferation of Institutional Acts of International Organizations: a Proposal for their Classification, Evolutions in the Law of International Organizations (edited by Roberto Virzo, Ivan Ingravallo) : Leiden; Boston : Brill; Nijhoff, 2015. 547 p.

9. Amerasinghe C. F. Principles of the Institutional Law of International Organizations. 2nd ed. New York : Cambridge University Press, 2005. 535 p.

10. Schermers Henry G., Blokker Niels M. International institutional law: unity within diversity. 5th rev. ed. Leiden; Boston : Martinus Nijhoff Publishers, 2011. 1273 p.

11. Международное право $=$ Völkerrecht $/$ Вольфганг Граф Витцтум [и др.] ; пер с нем., 2-е изд. / [В. Бергманн, сост.]. Москва : Инфотропик Медиа, 2015. 1072 с.

12. Bernhardt R. International Organizations in General, Universal International Organizations, and Cooperation. Encyclopedia of Public International Law. Amsterdam : North Holland, 1983. 426 p.

13. Seyersted F. Common Law of International Organizations. Leiden; Boston : Martinus Nijhoff Publishers, 2008. 605 p.

14. Енциклопедія міжнародного права : у 3 т. / редкол.: Ю. С. Шемшученко, В. Н. Денисов (співголови) та ін., ; Інститут держави і права ім. В. М. Корецького НАН України. Т. 1. А-Д. Київ : Академперіодика, 2014.920 с.

15. Balladore Pallieri G. Le droit interne des organisations internationales. 127 Recueil des Cours (1969/II). Hague Academy of International Law.

16. Віденська конвенція про право міжнародних договорів 1969 p. URL: https://zakon.rada.gov.ua/laws/show/995_118

17. Report of the International Law Commission on the work of its fifty-fifth session (5 May-6 June and 7 July-8 August 2003), Yearbook of the International Law Commission, Volume II, Part 2, 2003. UN Doc. A/CN.4/SER.A/2003/Add.1 (Part 2).

18. Lauterpacht, Q.C., E. The Development of the Law of International Organization by the Decisions of International Tribunals. 152 Recueil des Cours (1976/IV). Hague Academy of International Law.

19. Third Report on Identification of Customary International Law. International Law Commission. UN Doc. A/CN.4/682 (27 March 2015).

20. Vienna Convention on the Law of Treaties between States and International Organizations or between International Organizations, 1986. URL: https://legal.un.org/ilc/ texts/instruments/english/conventions/1 2 1986.pdf

21. Report of the International Law Commission on the work of its sixty-third session (26 April-3 June and 4 July-12 August 2011), General Assembly, Official Records, Sixtysixth session. Supplement No. 10 (A/66/10).

22. Статут Ради Європи 1949 p. URL: https://zakon.rada.gov.ua/laws/show/994_001

23. Charter of the United Nations and Statute of the International Court of Justice. URL: https://treaties.un.org/doc/publication/ctc/uncharter.pdf

24. Certain expenses of the United Nations (Article 17, paragraph 2, of the Charter), Advisory Opinion of 20 July 1962 : I.C.J. Reports 1962, p. 151-181. 


\section{Внутрішнє право міжнародних організацій}

25. Legal Consequences for States of the Contitiued Presence of South Africa in Namibia (South West Africa) notwithstanding Security Council Resolution 276 (1970), Advisory Opinion, I.C.J. Reports 1971, p. 16-66.

26. Specialized Agency Agreements. United Nations System Chief Executives Board for Coordination : офіц. веб-сайт. URL: https://www.unsystem.org/content/agreementsbetween-specialized-agencies-and-united-nations

27. Effect of awards of compensation made by the U. N. Administrative Tribunal, Advisory Opinion of July 13th, I954 : I.C. J. Reports 1954, p. 47-63.

\section{Ходаківська Д. М. Внутрішнє право міжнародних організацій}

Стаття присвячена 3'ясуванню особливостей внутрішнього права міжнародних організацій і його співвідношення з міжнародним правом.

Доводиться, що, хоча міжнародні організації в сучасному розумінні з'являються ще в 1919 р., питання їхнього «внутрішнього життя» протягом тривалого часу були позбавлені власного комплексу норм і регулювалися національним правом, колізійними прив'язками міжнародного приватного права та загальними принципами права. Подальше визнання необхідності існування внутрішнього права міжнародних організацій привело до формування двох протилежних позицій щодо його природи: як нового окремого правопорядку (sui generis) і як частини міжнародного права, хоч і відносно самостійної. У статті критично розглядаються обидві позиції та наводяться аргументи, що викликають сумніви в можливості рішуче схилитися до будь-якої з цих позицій. Зроблено висновок про неможливість однозначно визначити природу внутрішнього права міжнародних організацій, адже, з одного боку, основою внутрішнього права будь-якої міжнародної організації є міжнародний договір - установчий акт міжнародної організації, а з іншого боку, наявна істотна невідповідність між суб'єктами й джерелами міжнародного права та внутрішнього права міжнародних організацій.

Окрема увага приділена спробі визначити перелік джерел внутрішнього права міжнародних організацій на підставі наукових праць і роботи Комісії міжнародного права ООН: 1) установчий акт міжнародної організації; 2) ухвалені організацією акти, зокрема рішення та резолюції; 3) усталена практика організації; 4) укладені організацією угоди 3 третіми сторонами; 5) обов'язкові для організації судові чи арбітражні рішення. Окремо розглядається кожне з названих джерел.

Ключові слова: внутрішне право міжнародних організацій, міжнародне право, установчий документ міжнародної організації, правила міжнародної організації, внутрішньоорганізаційний механізм.

\section{Khodakivska D. Internal law of international organizations}

The article covers the identification of the peculiarities of internal law of international organizations and its relationship with international law.

It is substantiated that despite the fact that international organizations in the modern sense emerged in 1919, the issues of their "internal life" have long been deprived of their own body of rules and have been governed by national law, conflict of laws and general principles of law. The further recognition of the need for the existence of internal law of international organizations has led to the formation of the two opposite positions concerning its nature: regarding this law as a new separate legal order (sui generis) and as part of international law, albeit relatively independent. In the article both positions are critically examined and arguments raising doubts on the possibility of definitively inclining to any of these positions are presented. It is concluded that it is impossible to unequivocally define the nature of internal law of international organizations, as on the one hand, the basis for internal law of an international organization is a treaty, the constituent instrument of an international organization, and on the other hand, there is a wide discrepancy between subjects and sources of international law and internal law of international organizations. 
Particular attention is paid to the attempt to determine the list of sources of internal law of international organizations on the basis of research papers and the work of the International Law Commission: 1) the constituent instrument of an international organization; 2) acts adopted by the organization, in particular decisions and resolutions; 3 ) established practice of the organization; 4) agreements concluded by the organization with third parties; 5) judicial or arbitral decisions binding the organization. Each of the aforementioned sources is examined separately.

Key words: internal law of international organizations, international law, constituent instrument of an international organization, rules of an international organization, internal organizational mechanism. 